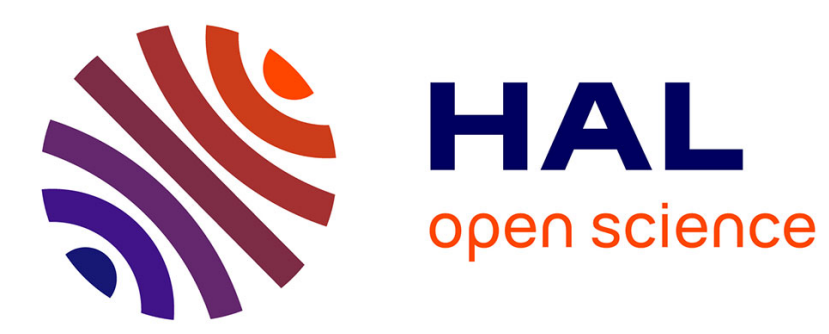

\title{
Wave-driven Groundwater Flows in Sandy Beaches: A Richards Equation-based Model
}

\author{
Jean-Baptiste Clément, Damien Sous, Frederic Golay, Mehmet Ersoy
}

\section{To cite this version:}

Jean-Baptiste Clément, Damien Sous, Frederic Golay, Mehmet Ersoy. Wave-driven Groundwater Flows in Sandy Beaches: A Richards Equation-based Model. Journal of Coastal Research, 2020, Proceedings from the 16th International Coastal Symposium, Special issue 95, pp.1047-1051. 10.2112/SI95-204.1 . hal-02899299

\section{HAL Id: hal-02899299 \\ https://hal.science/hal-02899299}

Submitted on 5 Mar 2021

HAL is a multi-disciplinary open access archive for the deposit and dissemination of scientific research documents, whether they are published or not. The documents may come from teaching and research institutions in France or abroad, or from public or private research centers.
L'archive ouverte pluridisciplinaire HAL, est destinée au dépôt et à la diffusion de documents scientifiques de niveau recherche, publiés ou non, émanant des établissements d'enseignement et de recherche français ou étrangers, des laboratoires publics ou privés. 


\title{
Wave-driven Groundwater Flows in Sandy Beaches: A Richards Equation-based Model
}

\author{
Jean-Baptiste Clément ${ }^{\dagger \neq}$, Damien Sous ${ }^{\dagger \S^{\star}}$, Frédéric Golay ${ }^{\ddagger}$, and Mehmet Ersoy ${ }^{\ddagger}$ \\ ${ }^{\dagger}$ Mediterranean Institute of \\ "Institute of Mathematics of \\ \$SIAME \\ Oceanography \\ Université de Toulon \\ Toulon \\ Université de Toulon \\ Univ. Pau \& Pays Adour \\ La Garde, France \\ La Garde, France
}

\begin{abstract}
A groundwater model is developed to simulate flows under the swash zone of sandy beach. Variably saturated beach is described by Richards equation, which is solved by the Rivage code thanks to a discontinuous Galerkin method. The SWASH code is used to simulate wave propagation in nearshore waters and compute suitable boundary conditions at the beachface to force Richards equation. An idealized case is considered to investigate the beach groundwater response to the action of swash cycles associated with long IG-like waves: infiltration/ exfiltration, water table, hydraulic head and pore velocities are outlined. A good qualitative agreement is found with observations from experimental studies in the literature.
\end{abstract}

ADDITIONAL INDEX WORDS: Groundwater, swash zone, seepage, forced coupling, numerical modelling.

\section{INTRODUCTION}

Groundwater dynamics in sandy beaches is a matter of interest since beach represents interface between land and open sea and accounts for a wide range of processes: biogeochemical cycles, sediment transport, diffusion of dissolved materials, fresh/salt water exchanges between ocean and coastal aquifer, etc. It is therefore directly involved in the anthropogenic issues in nearshore areas in the global context of climate change and growing urbanization: beach erosion, submersion, aquifer salinization, etc. Many laboratory and field studies have been devoted to understand groundwater flows inside sedimentary beaches (Heiss et al., 2015; Steenhauer et al., 2011). Observational approaches are however still limited to resolve the full spatio-temporal variability of governing variables, in particular the fields of head, saturation and flux. Numerical modelling stands out as a promising prospect, allowing to evaluate more accurately water table fluctuations, flow velocities or infiltrations/exfiltrations during swash events which are for now very difficult to measure directly. Nevertheless, up to now, few models have been devoted to the simulation of wavedriven groundwater flows and their scope remains limited ( $\mathrm{Li}$ and Barry, 2000; Malott, O'Carroll, and Robinson, 2016).

The swash zone is a dynamic region subject to wave action. Waves are covering and uncovering alternately the beach whose boundary is mobile, porous and characterized by complex flows of various natures which affect groundwater. That is another reason why grasping its dynamics as a whole is difficult. Laboratory experiments and field studies have revealed circulation pattern during the swash cycle. The flow is mainly directed offshore, with inflow in the upper part of the swash zone and exfiltration in the lower part (Sous et al., 2013; Sous et al., 2016; Turner et al., 2016). However, such features are expected to strongly depend on the saturation state of the beach and the duration and location of uprush/backwash phase, with significant consequences on seepage flows or rise of water table (Turner and Masselink, 1998; Turner and Nielsen, 1997).

This paper introduces a groundwater model of Rivage code, developed to provide insight into the circulation under sandy beach swash zone. A key-point of the study is the choice of Richards equation usually used to simulate water flow within unsaturated porous media. Due to the various space and time scales involved by the simulation as well as the strong non-linearities of Richards equation, the numerical scheme needs to be robust and versatile (Farthing and Ogden, 2017). The solution is performed through a discontinuous Galerkin framework alongside time adaptation. This method is currently a high trend in numerical simulation to reach desired resolution and accuracy (Dolejší and Feistauer, 2015).

In the present study, an idealized long wave swash event is tested to evaluate the ability of the model to simulate groundwater response to swash cycles. To this end, a weak coupling is considered: wave-resolving bed pressure data provided by the open-source SWASH code (Zijlema, Stelling, and Smit, 2011) is used as a beachface boundary condition in the Rivage code. Qualitative comparisons are carried out between numerical results from the model and observations from laboratory and experimental measurements found in the literature. Distinctive features of the unconfined coastal aquifer during swash cycles are selected and commented. In particular, discussion focuses evolution of seepage location across the beachface as well as global and local pattern of 
pressure and velocity field. The goal of this paper is to present a first case handled by a promising numerical tool. The findings will assist future studies to quantify effects of swash on groundwater flow in sandy beaches for more realistic cases.

\section{METHODS}

A numerical model is developed to simulate wave-driven groundwater flows in sandy beaches. For this purpose, Richards equation is used together with boundary conditions monitored by external data. Emphasis is given to Richards equation model.

\section{Groundwater Flow Model: Richards Equation}

Richards equation is a classic nonlinear parabolic equation to describe flow in variably saturated porous media:

$$
\partial_{t}(\theta(\psi))-\nabla \cdot(K(\psi) \nabla(\psi+z))=0
$$

where, $\psi$ denotes the pressure head $(\mathrm{cm}), \boldsymbol{K}$ the tensor of hydraulic conductivity $(\mathrm{cm} / \mathrm{h}), z$ the elevation $(\mathrm{cm})$ and $\theta$ the water content. Throughout this paper, hydraulic head $(\mathrm{cm})$ is also used: $h=\psi+z$. Equation (1) is called the mixed form of Richards equation because it involves both variables, $\theta$ and $\psi$ . This form was chosen because it is mass conservative and is applicable to a wide range of porous media (Farthing and Ogden, 2017). To close Equation (1), two constitutive laws are necessary for water content and hydraulic conductivity. Several relations are available. In this paper, analytical expressions given from an experiment (Vauclin et al., 1979) are used to model fine sand of fairly regular grain-size distribution, less than $1 \mathrm{~mm}$ diameter:

$$
(\boldsymbol{K}(\psi) ; \theta(\psi))=\left\{\begin{array}{c}
\left(\frac{K_{s} A}{A+|\psi|^{B}} \boldsymbol{I} ; \frac{\theta_{S} C}{C+|\psi|^{D}}\right), \text { if } \psi \leq 0 \\
\left(\boldsymbol{K}_{s} ; \theta_{s}\right), \text { if } \psi>0
\end{array}\right.
$$

where, $A, B ., C, D$ are empirical parameters, $K_{s}$ is hydraulic conductivity at saturation and $\theta_{s}$ is water content at saturation. It can be noticed that unsaturated and saturated zones are defined according to negative and positive $\psi$ values respectively. Reference (atmospheric) pressure is set as 0 and locates water table. Negative values of $\psi$ can be seen as suction where capillary forces are acting. Effective saturation $S_{e}$ is the water content which has been normalized. Flux $(\mathrm{cm} / \mathrm{h})$ is computed as:

$$
\boldsymbol{q}=-\boldsymbol{K}(\psi) \nabla(\psi+z)
$$

Richards equation is a widely used model for water flow in unsaturated soils and rocks (Szymkiewicz, 2013) and thus will be a priori suitable to model groundwater flow in sandy beaches. However, its limitations have to be kept in mind. First of all, flux is modelled as a generalized Darcy's law for two-phase flow, sometimes referred as Darcy-Buckingham's law. This is an empiric law which was first derived for creeping one-phase flow. Two limitations can be expected. First, this model is valid only where advective inertial forces are small compared with viscous forces. This is a strong assumption to be checked since turbulent and fast dynamics can occur at the beach boundary. Nevertheless, this study considers sandy beaches which act like low-pass filter. Small enough velocities are rapidly found beneath the boundary (Sous et al., 2016). The second point is generalization from onephase to two-phase flow which lacks rigour. Finally, the wellknown main hypothesis is elimination of air equation from the diphasic system to keep only water equation, which becomes Richards equation. Indeed, air viscosity is about 55 times smaller than the water viscosity. Consequently, it is assumed that pressure gradients balance faster in air than in water phase, and if air phase is connected continuously at every point with the atmosphere, then air equation is neglected. It means features like trapped air pockets or phenomena driven by air phase cannot be modelled (Szymkiewicz, 2013).

In regards to swash zone, Richards equation is a good, but still poorly used, candidate to explore both saturated and unsaturated beach dynamics. In particular, extensive experience is available in the subsurface hydrology community especially for its numerical resolution and its coupling with surface flows.

Richards equation holds strong non-linearities due to constitutive laws and boundary conditions. Moreover, it degenerates into an elliptic equation under complete saturation. Sharp wetting fronts can also happen according to initial and boundary conditions. For these reasons, designing a robust and general numerical tool can be troublesome (Farthing and Ogden, 2017). Rivage code was implemented to tackle these challenges. Richards equation is solved by fixed-point iteration with an implicit scheme and time adaptation. The discretization is performed with a discontinuous Galerkin framework to capture the range of scales arising in the swash situation thanks to space and order adaptation (Dolejší and Feistauer, 2015).

\section{Boundary Conditions for Forced Coupling and Seepage}

Surface and subsurface flows are a unified system by nature. For technical reasons (space/time scales, computational solvability), they are often divided into two submodels which work together though a coupling. Different coupling schemes are possible (Furman, 2008). The simplest one has been chosen for this study. It is called "forced coupling", "external coupling" or "weak coupling". Based on the solution of surface water submodel, a boundary condition is prescribed for the groundwater model. It means submodels are solved in succession, and so, the surface submodel cannot be corrected by feedback. One benefit of forced coupling is that implementation is straightforward because no infiltration/exfiltration model is necessary. This technic can approximate sandy beaches where pore velocities are too slow to affect surface water. Nevertheless, it goes without saying that coupling should gain in maturity by reckoning with an infiltration model or mass conservative principle, without considering retroaction.

The SWASH code simulates propagation of free surface waves according to selected input parameters at the offshore boundary. It is used here in a two-layer configuration, all parameters being kept by default (Zijlema, Stelling, and Smit, 2011). The space and time resolved bed pressure are extracted in order to enforce Richards equation by a space and time dependant Dirichlet boundary condition for hydraulic head. To complete this approach, a so-called seepage boundary condition (Scudeler et al., 2013) is prescribed wherever there are dry conditions, beyond the swash tip. In this way, the model can capture seepage faces, between 


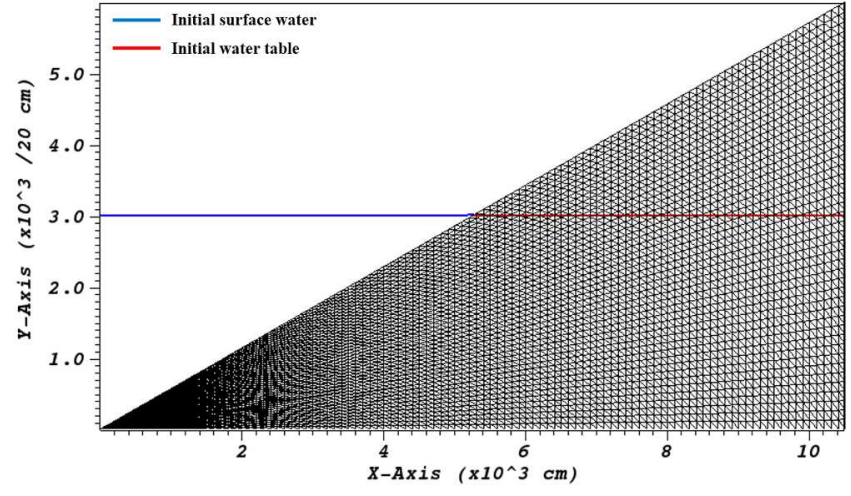

Figure 1. Topography of the idealized beach and mesh used for the simulation.

surface water and a higher phreatic surface. The seepage boundary condition reads as follow:

$$
\left\{\begin{array}{c}
\psi=0, \text { if } \psi \geq 0 \text { and } q \cdot n \geq 0 \\
q \cdot n=0, \text { otherwise }
\end{array}\right.
$$

In other words, if porous medium is saturated and there is outflow, then water pours out at atmospheric pressure. This condition is also called Signorini's type. It can be seen as a nonlinear Robin boundary condition since the length of seepage face is unknown a priori. The seaward seepage flow along beachface, as water is discharging, does not influence surface water.

\section{Description of the Idealized Beach Case}

Rivage code was previously validated with several test-cases for Richards equation. They involve various processes such as infiltration into soil columns or recharge/depletion/dewatering of water table. The aim of this paper is to assess an idealized beach case, forced by bed pressure data from the SWASH code.

The beach considered is a straight slope of ratio 1:35 which spans over 105 meters. Figure 1 shows the beach profile and the mesh used. Y-axis is multiplied by 20 to make it more visible.

Hydraulic properties for constitutive laws of Equation (2) are written in the Table 1. Initial conditions are hydrostatic with water table level at same height of surface water: $h_{0}=1.5 \mathrm{~m}$ (Figure 1).

The bottom is an impervious boundary: $\boldsymbol{q} \cdot \boldsymbol{n}=0$. The water table and head are kept fixed on the inland boundary: $h=1.5 \mathrm{~m}$. The beachface is monitored by the SWACH code in the way described in the precedent section.

Table 1. Parameters of constitutive laws for the idealized beach case, (Vauclin et al., 1979).

\begin{tabular}{ccc}
\hline \hline Parameters & Hydraulic conductivity & Water content \\
\hline $\mathrm{A} / \mathrm{C}$ & $2.99 \times 106$ & 40000 \\
$\mathrm{~B} / \mathrm{D}$ & 5.0 & 2.90 \\
Value at saturation & 35 & 0.30 \\
\hline
\end{tabular}

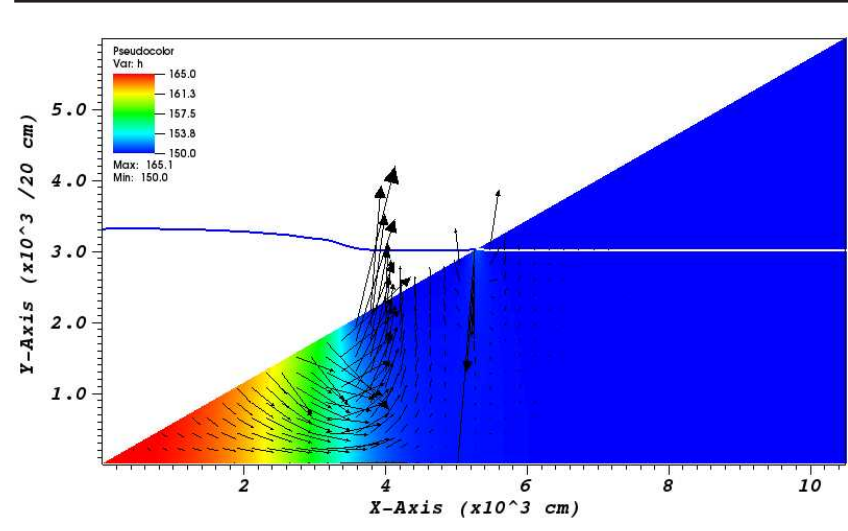

Figure 2. Snapshot of hydraulic head contours at $t=12.5 \mathrm{~s}$ during the first wave propagation on calm waters.

In SWASH, a sinusoidal time-series of free surface elevation is imposed at the offshore boundary to simulate a long infragravitylike wave of period $50 \mathrm{~s}$ and amplitude $0.3 \mathrm{~m}$. These types of waves have been observed to be a major driver of beach groundwater dynamics of the Rousty microtidal dissipative beach (Sous et al., 2016). This results in two swash events on the beachface. Time simulated lasts $120 \mathrm{~s}$.

\section{RESULTS}

An overview of groundwater features during a swash cycle is presented. Then, results focus on uprush and backwash events. Some selected snapshots from the simulation show interesting observations for the idealized beach case. Surface water and water table are depicted by blue and white solid lines respectively. Hydraulic head contours are displayed together with velocities vectors.

\section{Overall Pattern for Swash Cycles}

A first observation concerns wave propagation. When a wave is moving, groundwater flows in the saturated zone respond immediately. Hydraulic head spreads vertically quite sharply under the wave front. Infiltration/exfiltration occurs at the back/ front of the bore respectively. It is particularly visible in the Figure 2 even if this phase is completely ideal because it's about the first wave moving through hydrostatic conditions.

Throughout the simulation, a nearly hydrostatic state is observed in the upper beach area. Moreover, flow divides into seaward and landward components near the uprush limit. Velocities magnitude is rather small everywhere, about $1 \mathrm{~cm} / \mathrm{h}$, except for uprush infiltration at the top where it reaches up to $160 \mathrm{~cm} / \mathrm{h}$. Around exit point of water table, a local overpressure is observed. It is probably caused by numerical artefacts due to the lack of mesh resolution for the seepage boundary condition.

An overall pattern can be depicted for swash cycles. Two recirculation zones are attached respectively to the back and the front of the swash tongue. These two groundwater cells are interacting together and are evolving during uprush and backwash, growing or diminishing. Sometimes one vanishes completely; sometimes another one gets trapped by recharge induced by water table elevation. 


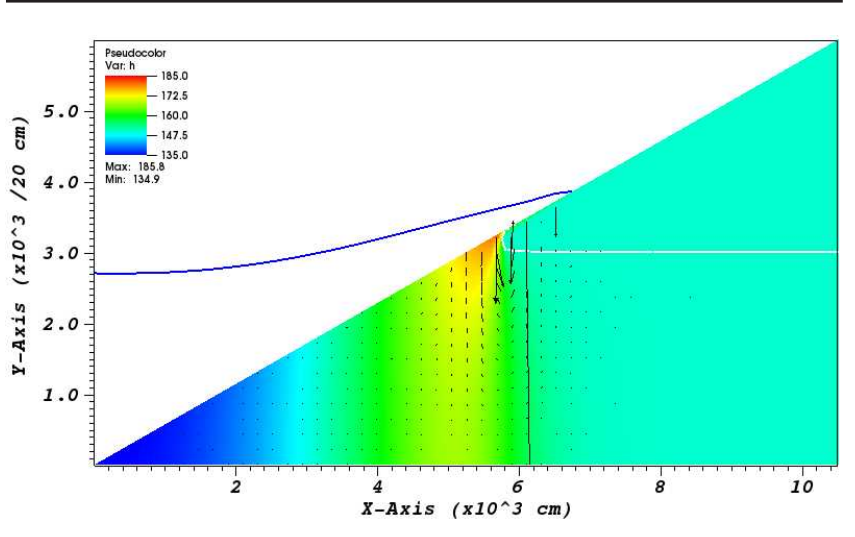

Figure 3. Snapshot of hydraulic head contours at $t=37.5 \mathrm{~s}$ for the end of the first uprush. Velocities range from about 0.3 to $0.6 \mathrm{~cm} / \mathrm{h}$ in the beach. Maximum velocity is $35 \mathrm{~cm} / \mathrm{h}$ for infiltration.

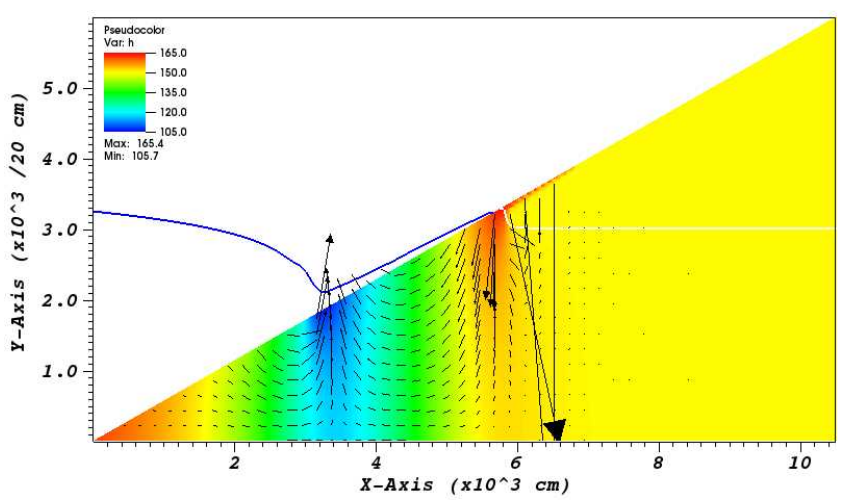

Figure 4. Snapshot of hydraulic head contours at $\mathrm{t}=57.5 \mathrm{~s}$ for the end of the first backwash. Most velocities are less than $1 \mathrm{~cm} / \mathrm{h}$.

\section{Pattern during Uprush Event}

During uprush, there is downward infiltration while the swash tongue is covering the beach. It is mainly concentrated in the upper zone, through the boundary in contact with the fully saturated part of the beach. Infiltration induces a rise of the water table near the exit point, with, as seen in Figure 3.

\section{Pattern during Backwash Event}

During backwash, a low hydraulic head zone emerges at the base of the swash zone where exfiltration occurs. Velocities are mainly seaward under the swash tongue moving back. Meanwhile, a small region of high hydraulic head persists in the corner of the saturated zone where water table have been raised by the precedent uprush. It results in recharge and, as water is percolating inside the porous medium, flow divides between seaward and landward direction. Moreover, above the unsaturated zone which has been covered by uprush, water is infiltrating downward in a sharp wetting front. While the swash toe retreating to the sea, a seepage face is appearing which drops, locally but quickly, the water table what gives form to a small hump-like structure? Figure 4 presents these observations.

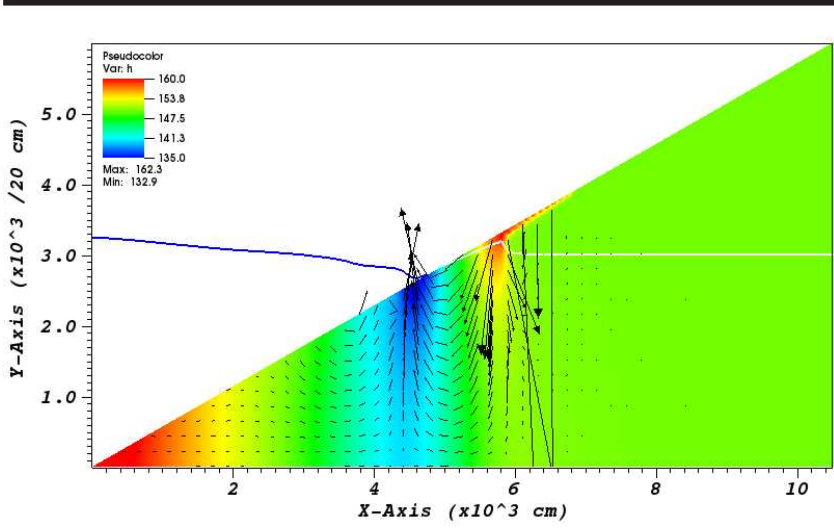

Figure 5. Snapshot of hydraulic head contours at $t=67.5 \mathrm{~s}$ for the next incoming uprush. Most velocities are less than $0.8 \mathrm{~cm} / \mathrm{h}$.

\section{Pattern between Backwash and Uprush Events}

The next incoming wave arrives just after the backwash. It pushes the region of low hydraulic head up. As this zone swept away, it reaches the remaining small region of high hydraulic head induced by the water table elevation and makes it disappear temporally.

The incoming wave is bringing a new high hydraulic head front. This causes infiltration which arises water table again, ending seepage and erasing the hump-like structure of water table. Then, a new cycle begins. This intermediate state is shown in Figure 5.

\section{DISCUSSION}

In the simulation, the offshore water level is similar to the inland water table, therefore no steady pressure gradient is observed across the beachface by contrast to field or laboratory studies where cross-beach gradients can be observed depending on boundary conditions (Sous et al., 2016; Turner et al., 2016).

Within the beach, overall velocity magnitude is about $1 \mathrm{~cm} / \mathrm{h}$ which is fairly comparable to measurements made in Sous et al. (2016). The only exception is for infiltration/exfiltration where maximum velocity order is about $100 \mathrm{~cm} / \mathrm{h}$. This seems to be less compared with the experiments of Turner et al. (2016). Further tests are now engaged in the exact configurations of the laboratory (Turner et al., 2016) and field (Sous et al., 2016) experiments to allow direct comparisons.

As described by Perera et al. (2019), the moving bore is carrying a sharp hydraulic front. Exfiltration occurs at its front and infiltration at its back when it meets the groundwater conditions of the precedent swash.

A local superelevation of the water table has also been revealed in these observational studies due to the water table charge by short or IG wave forcing under the swash zone. Perera et al. (2019) showed a domed water table in their study. The present benchmark case will be extended to a longer duration to test if the model is able to represent such feature.

Water table elevation induces charge in this zone as long as the low-pressure zone does not affect it with the ongoing uprush. As a consequence, infiltration with flow division occurs near the uprush limit. Laboratory experiments and numerical simulations (Li and Barry, 2000; Turner et al., 2016) both predict this feature but Sous et al. (2016) do not observe it. 
During the simulation, seepage face has small length because water is able to pour out from sand quite fast following surface water. As a consequence, a small hump-like structure appears during backwash because of seepage along the boundary. This last feature is not described in any study found, but further tests are ongoing with more realistic configurations and longer wave forcings to better understand involved processes.

The two circulation zones with infiltration/exfiltration in the upper/lower part of the beach are also identified in the simulation from Li and Barry (2000) and experiments from Turner et al. (2016). Infiltration and exfiltration involve greater pore velocities than in other parts of the beach. Like it is depicted by Perera (2019), gradients brought by the wave are much larger than the average values in the beach due to larger differences in water depth across the wave.

\section{CONCLUSIONS}

This paper deals with a numerical model supported by the Rivage code and built around Richards equation so that it can simulate wave-driven groundwater flows in sandy beaches. By generating waves, the SWASH code computes pressure on the bed to enforce Richards equation with a Dirichlet boundary condition. For this forced coupling, groundwater does not hold sway over surface water but this influence can be neglected if pore velocity is slow compared to wave velocities as it happens for beaches with fine grains. What is more, exfiltration by seepage can be modelled through the seepage boundary condition prescribed on the beachface wherever there is no enforced pressure.

Based on the simulation results from an idealized beach case, the following outlines can be drawn for a swash cycle:

- Groundwater pressure stays nearly hydrostatic under dry area, in the upper beach. Incoming waves propagate groundwater pressure front.

- The swash tongue causes overall infiltration during the bed flooding what elevates water table next to beachface and creates sharp wetting front in the unsaturated zone lapped by swash. For charge induced by water table, flow divides into landward and seaward components.

- $\quad$ During backwash, seaward groundwater can be observed under the swash tongue moving back to the sea. Water table exit point follows the swash toe with late because of sand hydraulic properties, resulting in seepage.

Two localized groundwater circulation zones evolve and interact during the simulation. One, associated with low pressure and exfiltration, is attached to the swash base during backwash and to the forefront of the next wave during uprush. The other one, associated with high pressure and infiltration, is attached to water table recharge during backwash and to the swash wave during uprush.

This general scheme is consistent with observations made by experimental studies in the literature. Further investigations are needed to assess, on the one hand, numerical effects on the solution, such as discretization level or boundary conditions and, on the other, physical parameters such as constitutive laws, beach topography or incoming waves.

\section{ACKNOWLEDGMENTS}

This work has been supported financially by Provence-AlpesCôte d'Azur region (France).

\section{LITERATURE CITED}

Dolejší, V. and Feistauer, M., 2015. Discontinuous Galerkin Method. Springer International Publishing.

Farthing, M.W. and Ogden, F.L., 2017. Numerical solution of Richards' equation: A review of advances and challenges. Soil Science Society of America Journal, 81(6), 1257-1269.

Furman, A., 2008. Modeling Coupled Surface-Subsurface Flow Processes: A Review. Vadose Zone Journal, 7(2), 741-756.

Heiss, J.W.; Puleo, J.A.; Ullman, W.J., and Michael, H.A., 2015. Coupled surface-subsurface hydrologic measurements reveal infiltration, recharge, and discharge dynamics across the swash zone of a sandy beach. Water Resources Research, 51(11), 8834-8853.

Li, L. and Barry, D., 2000. Wave-induced beach groundwater flow Advances in Water Resources, 23(4), 325-337.

Malott, S.; O'Carroll, D.M., and Robinson, C.E., 2016. Dynamic groundwater flows and geochemistry in a sandy nearshore aquifer over a wave event. Water Resources Research, 52(7), 5248-5264.

Perera, E.; Zhu, F.; Dodd, N.; Briganti, R.; Blenkinsopp, C., and Turner, I.L., 2019. Surface-groundwater flow numerical model for barrier beach with exfiltration incorporated bottom boundary layer model. Coastal Engineering, 146, 47-64.

Scudeler, C.; Paniconi, C.; Pasetto, D., and Putti, M., 2013. Swash-groundwater dynamics in a sandy beach laboratory experiment. Coastal Engineering, 80, 122-136.

Sous, D.; Lambert, A.; Rey, V., and Michallet, H., 2017. Examination of the seepage face boundary condition in subsurface and coupled surface/subsurface hydrological models. Water Resources Research, 53(3), 1799-1819.

Sous, D.; Petitjean, L.; Bouchette, F.; Rey, V.; Meulé, S.; Sabatier, F., and Martins, K., 2016. Field evidence of swash groundwater circulation in the microtidal rousty beach, France. Advances in Water Resources, 97, 114-155.

Steenhauer, K.; Pokrajac, D.; Donoghue, T.O., and Kikkert, G.A., 2011. Subsurface processes generated by bore-driven swash on coarse-grained beaches. Journal of Geophysical Research, 116(C4).

Szymkiewicz, A., 2013. Modelling Water Flow in Unsaturated Porous Media. Springer Berlin Heidelberg.

Turner, I.L. and Masselink, G., 1998. Swash infiltrationexfiltration and sediment transport. Journal of Geophysical Research: Oceans, 103(C13), 30813-30824.

Turner, I.L. and Nielsen, P., 1997. Rapid water table fluctuations within the beach face: Implications for swash zone sediment mobility? Coastal Engineering, 32(1), 45-59.

Turner, I.L.; Rau, G.C.; Austin, M.J., and Andersen, M.S., 2016. Groundwater fluxes and flow paths within coastal barriers: Observations from a large-scale laboratory experiment (BARDEX II). Coastal Engineering, 113, 104-106.

Vauclin, M.; Khanji, D., and Vachaud, G., 1979. Experimental and numerical study of a transient, two-dimensional unsaturatedsaturated water table recharge problem. Water Resources Research, 15(5), 1089-1101.

Zijlema, M.; Stelling, G., and Smit, P., 2011. SWASH: An operational public domain code for simulating wave fields and rapidly varied flows in coastal waters. Coastal Engineering, 58, 992-1012. 